\title{
Pembelajaran Fisika dengan Pendekatan Inkuiri Menggunakan Aplikasi Berbasis Android untuk Meningkatkan Prestasi Siswa
}

\author{
Suyono \\ Guru SMA Negeri 2 Madiun \\ Email: suyonosynway@gmail.com
}

\begin{abstract}
ABSTRAK
Tujuan dari penelitian ini adalah pembelajaran fisika melalui pendekatan inkuiri menggunakan aplikasi berbasis android dapat untuk meningkatan prestasi fisika pada siswa kelas XI IPA4 SMA Negeri 2 Madiun Tahun Pelajaran 2016/2017. Metode penelitian yang digunakan tindakan kelas (action research) yang terdiri dari 2 siklus. Setiap siklus terdiri 4 langkah yaitu perenacaan, tindakan, observasi dan refleksi. Teknik pengumpulan data dengan tes tertulis untuk prestasi fisika. Hasil penelitian menunjukkan pembelajaran dengan pendekatan inkuiri menggunakan aplikasi berbasis android dapat meningkatkan prestasi fisika belajar siswa yang ditandai dengan ketuntasan belajar siswa dalam pembelajaran yaitu dari $81,25 \%$ pada siklus I menjadi $94,11 \%$ pada siklus II dengan nilai rata-rata siswa 70,71 pada siklus I menjadi 80,71 pada siklus II.
\end{abstract}

Kata Kunci : Pendekatan inkuiri, aplikasi berbasis android

\section{Learning Physics with Inquiry Approach Using Android-Based Applications to Improve Student Achievements}

\author{
Suyono \\ Guru SMA Negeri 2 Madiun \\ Email: suyonosynway@gmail.com
}

\begin{abstract}
This study aims to determine the improvement of student learning outcomes with the inquiry approach using android-based applications in class XI IPA4 SMA Negeri 2 Madiun 2016/2017 Academic Year. Classroom action research methods (action research) data collected with written tests for knowledge. Learning with the inquiry approach using android-based applications has a positive impact in improving student learning achievement which is characterized by student learning completeness in learning that is from $81.25 \%$ in cycle I to $94.11 \%$ in cycle II with an average value of 70.71 students in cycle I it became 80.71 in cycle II.
\end{abstract}

Keywords: inquiry approach, android based application 


\section{PENDAHULUAN}

Berdasarkan beberapa pengalaman dari tahun-tahun yang lampau dalam pembelajaran Fisika SMA kususnya pada materi pokok Teori kinetik gas dengan Kompetensi Dasar Memahami teori kinetik gas dalam menjelaskan karakteristik gas pada ruang tertutup sebagaimana tercantum didalam Kurikulum 2013 sekolah kami, pada umumnya sekolah mengalami beberapa kesulitan yang disebabkan minimnya sarana serta keengganan para guru untuk melakukan praktikum di laboratorium di karenakan waktu yang tersedia sangat terbatas dan pengelolaan kelas pada metode praktikum lebih berat (dengar pendapat forum MGMPS SMA Negeri 2 Kota Madiun) hal ini berimbas pada rendahnya prestasi belajar siswa.

Pada materi pembelajaran fisika terdapat banyak rumus-rumus yang harus dipelajari siswa. Selain pembelajaran fisika, siswa SMA harus mempelajari rumus-rumus lain yang terdapat pada mata pelajaran yang lain seperti matematika, kimia. Hal ini menjadi salah satu permasalahan yang pokok untuk menghafal, memahami dan menerapkannya dalam pemecahan masalah yang terjadi di lingkungan sehari-hari. Berdasarkan masalah tersebut maka diperlukan media belajar yang cocok. Di era milenial dan digital sekarang ini media elektronik seperti handphone beserta aplikasinya sangatlah familier dikalangan pelajar SMA.

Media pembelajaran merupakan sesuatu yang dapat digunakan untuk menyampaikan pesan dari sumber secara terencana. Tujuan dari media pembelajaran salah satunya adalah dapat menciptakan proses pembelajaran menjadi kondusif dan efektif. (Rayanda Asyar, 2012 : 8) permasalahan yang terjadi di kelas XI.IPA 4 adalah lemahnya tingkat hafalan, pemahaman dan aplikasi rumus-rumus fisika, beberapa faktor tersebut diantaranya adalah: 1) proses dalam pembelajaran sering dilakukan hanya dengan metode ceramah, dan 2) peran media pembelajaran yang kurang optimal untuk menunjang proses pembelajaran.

Oleh karena hal tersebut di atas maka peneliti mencoba menanganinya dengan menggunakan pendekatan inkuiri menggunakan aplikasi pembelajaran yang berbasis Android untuk memecahkan masalah tersebut. 
Berdasarkan landasan teori dan kerangka pemikiran di atas maka dapat dirumuskan hipotesis penelitian tindakan kelas adalah: 1) Dapat meningkatkan kualitas pembelajaran dan prestasi siswa di kelas sehingga siswa secara umum dapat termotivasi untuk meningkatkan proses belajarnya dalam menghafal,memahami dan menerapkan teori dan rumus-rumus fisika dalam penyelesaian permasalahan sehari-hari. 2) Dari sisi peneliti (guru) diharapkan dapat meningkatkan profesionalisme dalam melakukan tugas mengajar agar siswa lebih termotivasi sehingga dapat meningkatkan prestasi belajar siswa. Kemudian dari sisi institusi (sekolah) dapat memberi informasi yang berupa masukan kepada seluruh warga sekolah untuk selalu berpaya meningkatkan kemampuan dalam mengatasi masalah pendidikan terutama dalam pembelajaran di kelas dengan mengacu pada metode ilmiah.

\section{METODE}

Metode Penelitian ini yang digunakan pada penelitian ini adalah penelitian tindakan (action research). Penelitian tindakan ini bertujuan untuk memecahkan masalah pembelajaran di kelas. Analisis pada penelitian ini menggunakan analisis deskriptif kuantitatif. Hal ini dapat menjabarkan teknik pembelajaran yang diterapakan sesuai dengan langkah pembelajaran sehingga dapat mencapai target sesuai dengan indikator keberhasilan yang ditunjukkan melalui nilai prestasi siswa.

Klasifikasi penelitian tindakan terdiri dari 4 macam yaitu a) guru sebagai penelitian. b) penelitian tindakan kolaboratif. c) simultan terintegratif. (d) administrasi social eksperimental (Oja dan Sumarjan dalam Titik Sugiarti, 1997: 8). Sedangkan pada penelitian tindakan ini menggunakan bentuk guru sebagai peneliti. Hal ini guru sebagai penanggung jawab penuh terhadap penelitian tindakan. Penelitian tindakan ini bertujuan untuk meningkatkan prestasi siswa melalui pembelajaran di kelas. Guru secara penuh bertanggungjawab atas penelitian mulai dari perencanaan, tindakan, pengamatan, dan refleksi. Pada penelitian ini peneliti tidak bekerjasama dengan siapapun, kehadiran peneliti sebagai guru di kelas sebagai pengajar tetap dan dilakukan seperti biasa, sehingga siswa tidak tahu kalau diteliti. Dengan cara ini diharapkan didapatkan data yang seobjektif mungkin demi kevalitan data yang diperlukan. Tempat penelitian ini 
dilakukan di Kelas XI.IPA.4 SMA Negeri 2 Kota Madiun semester genap tahun Pelajaran 2016/2017. Waktu pelaksanaan penelitian ini dilakukan pada bulan Februari Maret 2017 semester genap tahun pelajaran 2016/2017. Penelitian ini menggunakan instrumen yaitu 1) Silabus. Silabus digunakan untuk mengatur kegiatan pembelajaran pengelolahan kelas, serta capaian penilaian hasil belajar yang sudah terrencana. 2) Rencana Program Pembelajaran (RPP) merupakan perangkat pembelajaran yang digunakan sebagai pedoman guru dalam mengajar dan disusun untuk tiap pertemuan pada masing-masing siklus. Masing-masing RPP berisi kompetensi dasar, indikator pencapaian hasil belajar, tujuan pembelajaran, dan kegiatan belajar mengajar. 3.) Media aplikasi Pembelajaran interaktif yang disusun peneliti berisikan materi yang akan dipelajari dengan melalui program Flash yang di publikasikan dalam bentuk file dengan extention swf. Penggunaan pembelajaran di HP Android melalui Aplikasi Flash Game Player yang secara gratis dapat diunduh di Google Play. Tampilan menu utama dalam Aplikasi ini adalah sebagai berikut:

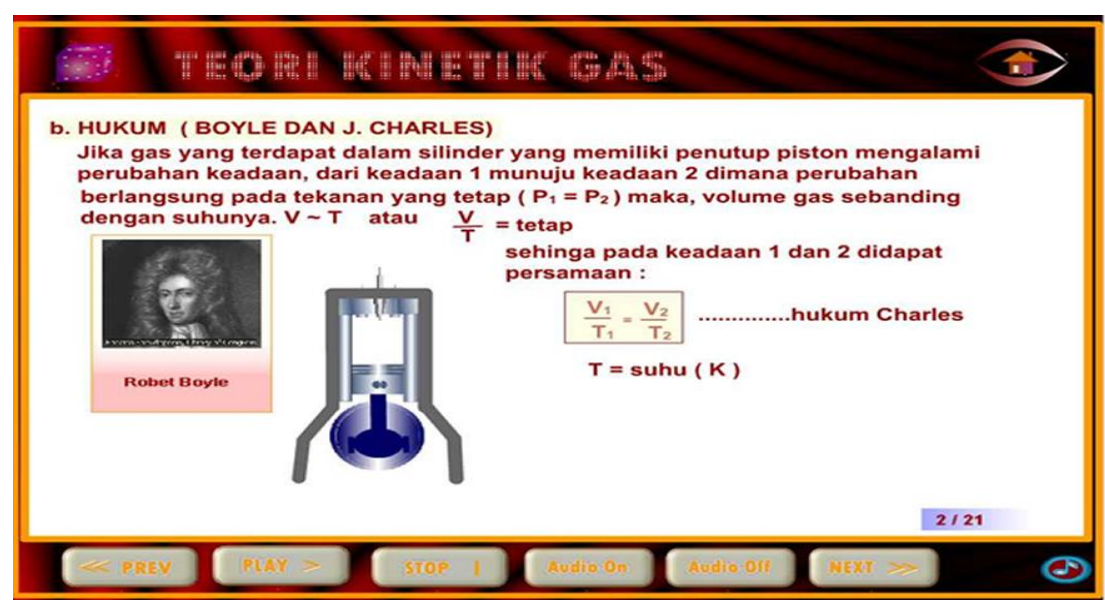

Gambar 1. Tampilan aplikasi pembelajaran

\section{HASIL DAN PEMBAHASAN}

Data penelitian yang diperoleh berupa hasil uji coba item butir soal, data observasi berupa pengamatan pengelolaan belajar dengan penerapan pendekatan inkuiri menggunakan Aplikasi pembelajaran berbasis Android dan pengamatan aktivitas siswa dan guru pada akhir pembelajaran, dan data tes siswa pada setiap siklus. Data hasil uji coba item butir soal digunakan untuk mendapatkan tes yang betul-betul mewakili apa yang diinginkan. Data ini selanjutnya dianalisis tingkat validitas, reliabilitas, taraf 
kesukaran, dan daya pembeda. Data tes untuk mengetahui peningkatan prestasi belajar siswa setelah diterapkan belajar.

\section{Siklus I}

Tabel 2. Rekapitulasi Hasil Tes Pada Siklus I

\begin{tabular}{clc}
\hline No & Uraian & Hasil Siklus I \\
\hline 1 & Nilai rata-rata tes & 7,71 \\
2 & Jumlah siswa yang tuntas belajar & 26 \\
3 & Jumlah siswa yang belum tuntas & 6 \\
4 & Persentase ketuntasan belajar & $81,25 \%$ \\
\hline
\end{tabular}

Dari tabel di atas dapat dijelaskan bahwa dengan pendekatan inkuiri menggunakan aplikasi berbasis android diperoleh nilai rata-rata prestasi belajar siswa adalah 7,71 dan ketuntasan belajar mencapai $81,25 \%$ atau ada 32 siswa dari 26 siswa sudah tuntas belajar. Hasil tersebut menunjukkan bahwa pada siklus pertama secara klasikal siswa tuntas belajar, karena siswa yang memperoleh nilai $\geq 67$ sebanyak 26 lebih besar dari siswa yang belum tuntas sebesar 6 siswa.

\section{Siklus II}

Tabel .2. Rekapitulasi Hasil Tes Pada Siklus II

\begin{tabular}{clc}
\hline No & \multicolumn{1}{c}{ Uraian } & Hasil Siklus II \\
\hline 1 & Nilai rata-rata tes & 8,71 \\
2 & Jumlah siswa yang tuntas belajar & 31 \\
3 & JUmlah siswa yang belum tuntas & 1 \\
4 & Persentase ketuntasan belajar & $96,87 \%$ \\
\hline
\end{tabular}

Dari tabel di atas dapat dijelaskan bahwa dengan pendekatan inkuiri menggunakan aplikasi berbasis android diperoleh nilai rata-rata prestasi belajar siswa adalah 8,71 dan ketuntasan belajar mencapai $96,87 \%$ atau ada 31 siswa dari 32 siswa sudah tuntas belajar. Hasil tersebut menunjukkan bahwa pada siklus pertama secara klasikal siswa 
tuntas belajar, karena siswa yang memperoleh nilai $\geq 67$ sebanyak 32 lebih besar dari siswa yang belum tuntas sebesar 1 siswa.

\section{SIMPULAN DAN SARAN}

Berdasarkan hasil pembahasan di atas maka dapat disimpulkan sebagai berikut: Pembelajaran dengan pendekatan inkuiri menggunakan aplikasi berbasis android memiliki dapat meningkatkan prestasi fisika. Hal ini dapat dilihat dari nilai ketuntasan belajar siswa dalam pembelajaran fisika yaitu pada siklus 1 sebesar 81,25\% meningkat menjadi $94,11 \%$ pada siklus II. Sedangkan nilai rata-rata prestasi fisika siswa 70,71 pada siklus I menjadi 80,71 pada siklus II. Secara tidak langsung dapat berdampak pada peningkatan motivasi belajar siswa. Berdasarkan hasil wawancara menunjukkan bahwa dalam pembelajaran fisika pada materi aplikasi pembelajaran teori kinetic melalui android.

Hasil penelitian yang menunjukkan proses belajar mengajar Fisika lebih efektif dan lebih memberikan hasil yang optimal bagi siswa, maka disampaikan saran sebagai berikut: 1) dalam pembelajaran pendekatan inkuiri berbasis android memerlukan persiapan yang cukup matang. Guru harus mempu menentukan atau memilih topik yang benar-benar bisa menerapkan dengan pembelajaran interaktif menggunakan aplikasi android pada proses belajar mengajar sehingga diperoleh hasil yang optimal. 2) guru hendaknya melatih siswadengan menggunakan pendekatan inkuiri, walau dalam taraf yang sederhana. Sehingga siswa dapat menemukan pengetahuan baru, memperoleh konsep dan keterampilan, dan mampu memecahkan masalah-masalah yang dihadapinya. 3) penelitian dapat digunakan sebagai rujukan pada penelitian selanjutnya dan permasalahan yang sejenis sehingga dapat dilakukan perbaikan-perbaikan agar diperoleh hasil yang lebih baik.

\section{DAFTAR REFERENSI}

Ali, Muhammad. 1996. Guru Dalam Proses Belajar Mengajar. Bandung: Sinar Baru Algesindon.

Arikunto, Suharsimi. 1993. Manajemen Mengajar Secara Manusiawi. Jakarta: Rineksa Cipta. 
Arikunto, Suharsimi. 1998. Prosedur Penelitian Suatu Pendekatan Praktek. Jakarta: Rineksa Cipta

Combs. Arthur. W. 1984. The Profesional Education of Teachers. Allin and Bacon, Inc. Boston.

Departemen Pendidikan dan Kebudayaan, 1994. Petunjuk Pelaksanaan Proses Belajar Mengajar, Jakarta. Balai Pustaka.

Asyhar, Rayanda. 2012. Kreatif Mengembangkan Media Pembelajaran. Jakarta: Gaung Persada (GP) Press Jakarta. 